\title{
The Effect of Road Culverts on the Benthic Macroinvertebrate Community in Wadeable Lotic Ecosystems
}

Travis Peterson

Portland State University

Follow this and additional works at: https://pdxscholar.library.pdx.edu/mcnair Let us know how access to this document benefits you.

\section{Recommended Citation}

Peterson, Travis (2010) "The Effect of Road Culverts on the Benthic Macroinvertebrate Community in Wadeable Lotic Ecosystems," PSU McNair Scholars Online Journal: Vol. 4: Iss. 1, Article 8.

https://doi.org/10.15760/mcnair.2010.52 
Portland State University McNair Research Journal 2010

The effect of road culverts on the benthic macroinvertebrate community in wadeable lotic ecosystems

by

Travis Peterson

Faculty Mentor:

Yangdong Pan

Citation: Peterson, Travis. The effect of road culverts on the benthic macroinvertebrates in wadeable lotic ecosystems. Portland State University McNair Scholars Online Journal, Vol. 4, 2010: pages [52-74] 


\title{
The effect of road culverts on the benthic macroinvertebrate community in wadeable lotic ecosystems
}

Travis Peterson

Yangdong Pan, Faculty Mentor

\begin{abstract}
Roads and lotic ecosystems intersect as their paths unfold across the landscape. At their intersections lotic ecosystems are often routed underneath a road through a culvert. Road culverts allow the transportation system and lotic ecosystem to coexist, but their presence can introduce physical stress on the local ecology. The purpose of this study was to investigate the effects of road culverts on the benthic macroinvertebrate community. I collected physical habitat, water quality, and benthic macroinvertebrate data from three sample units near the culverted sections of two lotic ecosystems. Sample units were positioned in a longitudinal configuration with a reference sample unit located above the road culvert, a study sample unit below the outlet, and a recovery sample unit further downstream. Non-metric MultiDimensional Scaling and Bray-Curtis distance showed an alteration of the benthic macroinvertebrate community at the study sample units when compared to reference conditions. In the study sample units, the benthic macroinvertebrate community was composed of a greater proportion of stressor-tolerant taxa, as assessed by the presence of Ephemeroptera, Plecoptera, and Trichoptera taxa. There was also an alteration of dominant feeding groups in the study sample units. This study shows a fundamental shift of the local lotic ecology below road culverts.
\end{abstract}




\section{Introduction}

Lotic ecosystems are characterized by the interactions of biotic and abiotic constituents in an area of flowing water over a period of time. They are open systems, characterized by their spatial and temporal heterogeneity, which can be translated into spatial and temporal dimensionality. Included in the spatial dimensions of a lotic ecosystem are: longitudinal (upstream downstream interactions), lateral (interactions through the flood plain), and vertical (interactions of the lotic system and the contiguous groundwater) dimensions. The three spatial dimensions are structured by the fourth dimension, which is time. These four dimensions and their interactions can elucidate patterns and processes within a lotic ecosystem and detect alterations from perceived normal conditions (Ward 1989).

Lotic ecosystems are long linear systems that are vulnerable to anthropogenic stressors along their longitudinal dimension, often times by the transportation network. The transportation network can cross a lotic ecosystem in a number of ways, including bridges, fords, and road culverts. As lotic ecosystems meander across the landscape, roads commonly intersect them, and the flowing water is directed under the road through a culvert. On the lands in Oregon and Washington managed by Bureau of Land Management and Forest Service, there are at least 10,000 culverts in fish-bearing lotic ecosystems. This estimate was based on road culverts that affect the upstream movement of certain fish species. The number of culverts in all lotic ecosystems is not officially known (United States General Accounting Office 2001). Depending on the type of crossing, there can be a range from relatively little to drastic impacts on the lotic ecosystem (Jackson 2003).

Road culverts can detrimentally affect a lotic ecosystem. The physical environment is altered from its pre-culverted state when a lotic ecosystem is directed through a road culvert 
(Foreman et. al. 2003; Jackson 2003). Road culverts can affect the longitudinal movement of substrate and large woody debris (Jackson 2003). The velocity of the lotic system is locally increased during spates due to a constriction of the channel, which can lead to lateral, longitudinal, and/or vertical erosion below the road culvert outlet and deposition further downstream (Abt and Thompson 1996; Foreman et. al. 2003) or a scour pool formation directly below the road culvert outlet (Abt and Thompson 1996). The overall affect of a road culvert along a flowing section of water is the alteration of the lotic ecosystem (Foreman et. al. 2003; Jackson 2003).

The alteration of the lotic ecosystem leads to several negative effects on biota. Upstream migration and instream movement of fish species is blocked or altered (Warren and Pardew 1998; Jackson 2003). Road culverts similarly affect the non-insect macroinvertebrate community in that their ability to disperse upstream and within the stream is negatively affected (Resh 2004; Vaughn 2002). In addition to disturbing migration and instream movement, culverts can also affect the composition of the benthic macroinvertebrate community. Kahn and Colbo (2008) found that the abundance of some benthic macroinvertebrates decrease below the road culvert outlet compared to reference conditions.

Benthic macroinvertebrates are found in all lotic ecosystems. These organisms have evolved a habitat-specific physiology and morphology, and distinct communities form along environmental gradients. The structure and function of these communities are shaped by both the physical and chemical stressors of their environment (Hauer and Resh 2006). The relationship of the benthic macroinvertebrate community to its environment is an intimate one, which allows these organisms to serve as indicators of environmental stress. The ecological 
affects of stressors can be identified by relating the autecologies of these organisms to the perceived environmental stressors (Carter et. al. 2006).

This study investigates the effects of a road culvert on the benthic macroinvertebrate community of a lotic ecosystem. Identified changes to the benthic macroinvertebrate community will aid in the understanding of the ecological impacts from a road culvert. The specific aims of this study are to identify whether there is an alteration of community composition, sensitive taxa, and/or functional feeding groups and what characteristics may control the structure of the benthic macroinvertebrate community when a lotic ecosystem is routed through a road culvert.

\section{Materials and Methods}

\section{Study Area}

This study was conducted in the 34,398-hectare Scappoose Bay Watershed (SBW). The

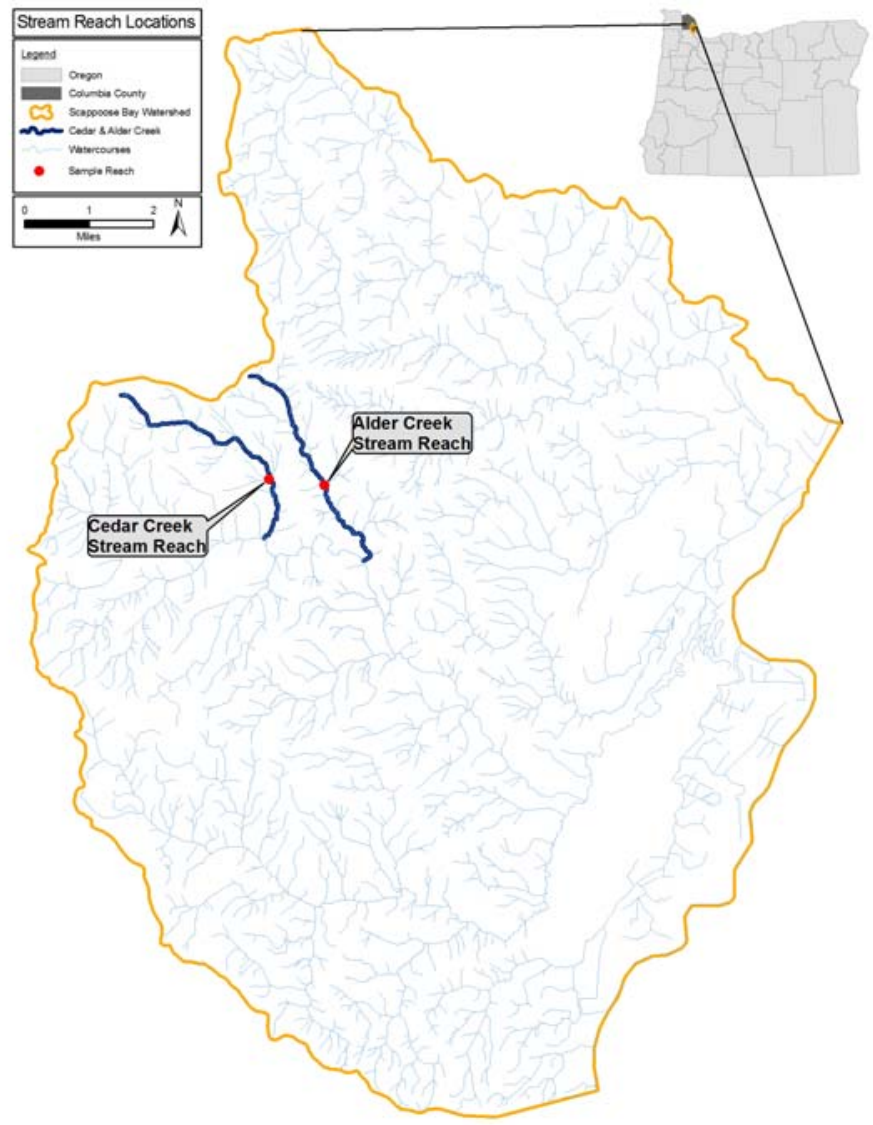

Figure 1. Map of the SBW in Oregon showing the location of Alder Creek and Cedar Creek as well as the locations of the stream reaches.
SBW is located in Columbia County, Oregon and drains to Scappoose Bay and the Columbia River through a rural landscape characterized by coastal hills, stream valleys, and lowland wetlands (David Evans and Associates, Inc. 2000). Data were collected from two stream reaches within the watershed (Figure 1), one located on Alder Creek (lat: 4550'21.1"N, long: 12257'31.9"W) and one located on Cedar Creek (lat: 4550'23.4"N, long: 12258'35.9"W), both 
of which are third-order perennial lotic systems. Data were collected from the Alder Creek stream reach on May 9, 2009, and from the Cedar Creek stream reach on May 31, 2009.

\section{$\underline{\text { Study Design }}$}

Sample units were the basic unit in which, physical habitat, water quality, and benthic macroinvertebrate data were collected. They were positioned (Figure 2) in a longitudinal configuration with a reference sample unit above the culvert, a study sample unit immediately below the road culvert outlet, and a recovery sample unit further downstream. The reference sample unit represented normal conditions. The study sample unit represented conditions that may be experiencing stress from the road culvert. The recovery sample unit represented conditions that may have returned to normal conditions. Sample units were sized according to the length of the scour pool.

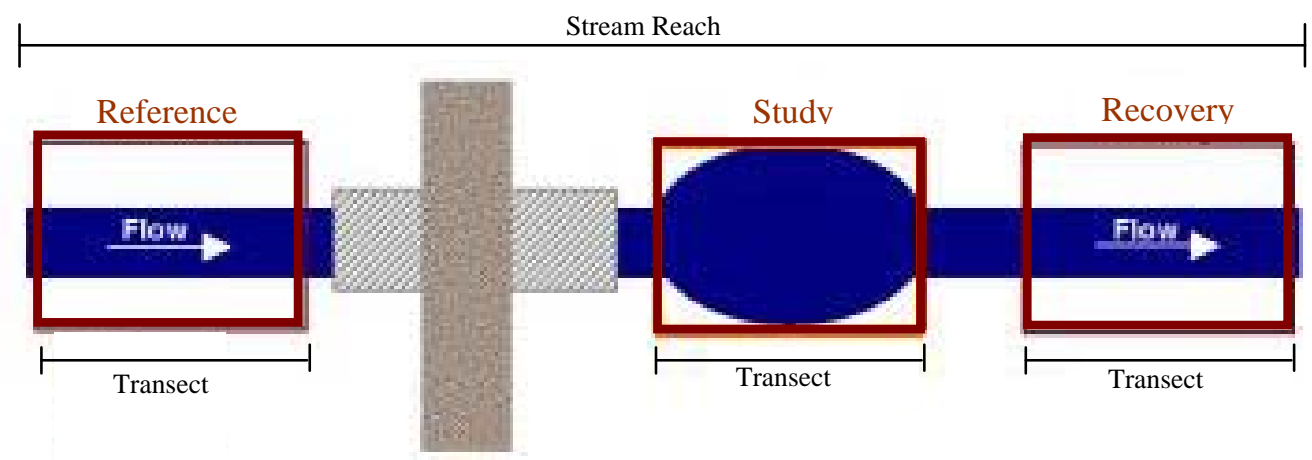

Figure 2. Configuration of sample units within stream reaches, also showing transect locations along sample units.

A 30-m measuring tape was used to measure the distance parallel to the stream channel from the road culvert outlet to a point where the scour pool was no longer evident. This measurement established the size of the sample units for that particular stream reach.

The sample units in this study were composed of highly variable instream habitat from two distinct Channel Geomorphic Units (CGUs): riffles and scour pools. In order to collect benthic macroinvertebrates representative of the CGUs, I used methods derived from Barbour et. al. (1999), which were necessary to collect benthic macroinvertebrates representative of the 
CGUs. The proportion of major instream microhabitat was estimated by counting habitat occurrence, at certain positions, across the width of the channel from set distances on a transect laid out parallel to the stream channel within each sample unit. This method provided a standardized estimation of major instream microhabitat within a sample unit. The observer moved along the transect from one end of the sample unit to the other while scanning across the channel, recording each major habitat within the stream on the left, one-third, center, two-thirds, and right channel areas. The observer then shifted approximately $0.5 \mathrm{~m}$ along the transect, repeating the observation process until the end of the transect. The count of each major instream microhabitat was divided by the total habitat count to calculate percentage of each major instream microhabitat. For the purposes of this study, major instream microhabitats (Barbour et. al 1999) included cobble, snags, vegetated banks, submerged macrophytes, as well as sands and other fines. An additional category, bare, was included in order to accommodate those spots that were more like exposed bedrock (Table 1).

\begin{tabular}{|r|r|}
\hline \multicolumn{1}{|c|}{ Description } \\
\hline Cobble & Rocks larger than 2mm in diameter \\
\hline Snags & Submerged woody debris \\
\hline Vegetated Banks & Exposed roots, emergent plants, submerged terrestrial plants \\
\hline Submerged Macrophytes & Aquatic plants \\
\hline Sands and Other Fines & Sand, clay, and other rocks $<2 \mathrm{~mm}$ in diameter \\
\hline Bare & Exposed bedrock \\
\hline
\end{tabular}

Table 1. Description of each type of instream microhabitat surveyed in this study.

Substrate was characterized with methods derived from Wolman (1954). From the downstream edge of the sample unit, the observer walked the width of the channel, from one bank to the other, in a heel-toe step fashion, picking up the first rock touched by the index finger at the toe of each step. This rock was then measured using a Gravelometer. Rocks too large to pass through the Gravelometer template were measured with the scale on its side. When the 
width of the channel had been crossed, the observer shifted approximately $0.5 \mathrm{~m}$ upstream and repeated the process. At least 100 samples were measured per sample unit.

The measurement of fine sediment cover was conducted in tandem with the Wolman pebble count. A random number generator was used to select five numbers, each with values between 1 and 100, which corresponds with the minimum number of samples taken for the pebble count. During the pebble count, when the sample was reached that corresponded with the random number that was selected, a 4-cm ${ }^{2}$ 81-square grid was dropped to the right of the observer. The cells that could be identified as being mostly fine sediment, as determined by professional judgment as being less than $2 \mathrm{~mm}$ in diameter, were counted. The average of the five samples was used to calculate the percentage of fine sediment cover per sample unit.

Wetted channel width measurements were taken at the one-third, one-half, and two-thirds longitudinal locations of the reference, study, and recovery sample units using a 30-m measuring tape. Stream depth and velocity were measured at the center channel of these locations. Depth was measured with a 1-m metal ruler. Velocity was measured using a Flo-Mate Portable Velocity Meter (Model 2000).

A YSI 556 Multiprobe System was used to measure dissolved oxygen, $\mathrm{pH}$, conductivity, total dissolved solids, and temperature. The measurements were taken near the center of each sample unit with the probe completely submerged, but suspended above the channel bottom.

Canopy cover was estimated using a concave Spherical Densiometer. From near the center of the sample unit, the observer took measurements in each cardinal direction. A canopy cover average was calculated from the four measurements.

Benthic macroinvertebrates were collected using an $800-\mu$ m mesh D-frame net. Five macroinvertebrate samples were taken from each sample unit in proportion to instream 
microhabitat. For example, if the sample unit was $80 \%$ cobble and $20 \%$ vegetated banks, four samples would be taken from cobble and one from vegetated banks. The five benthic macroinvertebrate samples were combined and preserved in 91\% alcohol, creating one composite sample. This process was repeated in each sample unit. Specific methods, as described by Barbour et. al (1999), were used to collect benthic macroinvertebrates from different instream microhabitats. While the sampling protocol differed for each habitat, the duration of collection was limited to 30s in order to establish standardization in sampling between microhabitats (Table 2).

\begin{tabular}{|r|l|}
\hline Microhabitat & \multicolumn{1}{|c|}{ Collection Method } \\
\hline Cobble & $\begin{array}{l}\text { D-frame net is placed on the bottom of the stream and 0.25-m } \\
\text { of substrate directly above the net is disturbed by shifting the } \\
\text { substrate. } \\
\text { When large rocks are present they were rubbed and lifted or } \\
\text { shifted. }\end{array}$ \\
\hline Snags & $\begin{array}{l}\text { Strongly disturb habitat and sweep a D-frame net back and } \\
\text { forth through the debris. }\end{array}$ \\
\hline Vegetated Banks & $\begin{array}{l}\text { Jab D-frame net into microhabitat and swept through the debris } \\
\text { multiple times. }\end{array}$ \\
\hline Submerged Macrophytes & $\begin{array}{l}\text { Drag D-frame net from the bottom to the top of macrophytes } \\
\text { area repeatedly. }\end{array}$ \\
\hline Bare & $\begin{array}{l}\text { Place D-frame net on surface and rub 0.25-m }{ }^{2} \text { of the surface } \\
\text { directly above the net. }\end{array}$ \\
\hline
\end{tabular}

Table 2. Specific collection methods used for each type of instrem microhabitat.

Benthic macroinvertebrates were identified to family level in the laboratory using a 20X dissecting microscope. Each benthic macroinvertebrate composite sample was counted as completely as possible by examining small sample quantities at a time. Merritt and Cummins (1996) and McCafferty and Provonsha (1998) were used as the major taxonomic references.

All data were compiled in spreadsheets, organized by stream reach and sample unit. Macroinvertebrate distributional patterns were summarized using non-metric multidimensional scaling (NMDS), a multivariate ordination technique commonly used in ecological community 
analysis (Clarke 1993). Bray-Curtis dissimilarity index was calculated among the sites. The NMDS projects each site in a species-defined ordination space with 2-3 dimensions based on their ranked dissimilarity. The goodness-of-fit for the NMDS projections was measured as a stress value which measures a deviation from a monotonic relationship between the distance among sites in the original Bray-Curtis dissimilarity matrix and the distance among sites in the ordination plot. The NMDS was run 20 times each with a random starting configuration. The final NMDS dimension was selected based on the lowest stress value among the best solutions. Environmental fitting was performed on benthic macroinvertebrate, physical habitat and water quality data to identify which environmental variable may best correlate with changes in macroinvertebrates. Both NMDS and environmental fitting were performed using R (Anon. 2004).

\section{Results}

Compared to the reference and recovery sample units the study sample units were considerably altered. The major alterations of instream microhabitat (Figure 3) occurred in the habitat types of cobble and sands and other fines. When compared to the reference and recovery sample units, the percent cover of cobble microhabitat in the study sample units decreased by about half, and the percent cover of sand and other fines increased by about four times. 


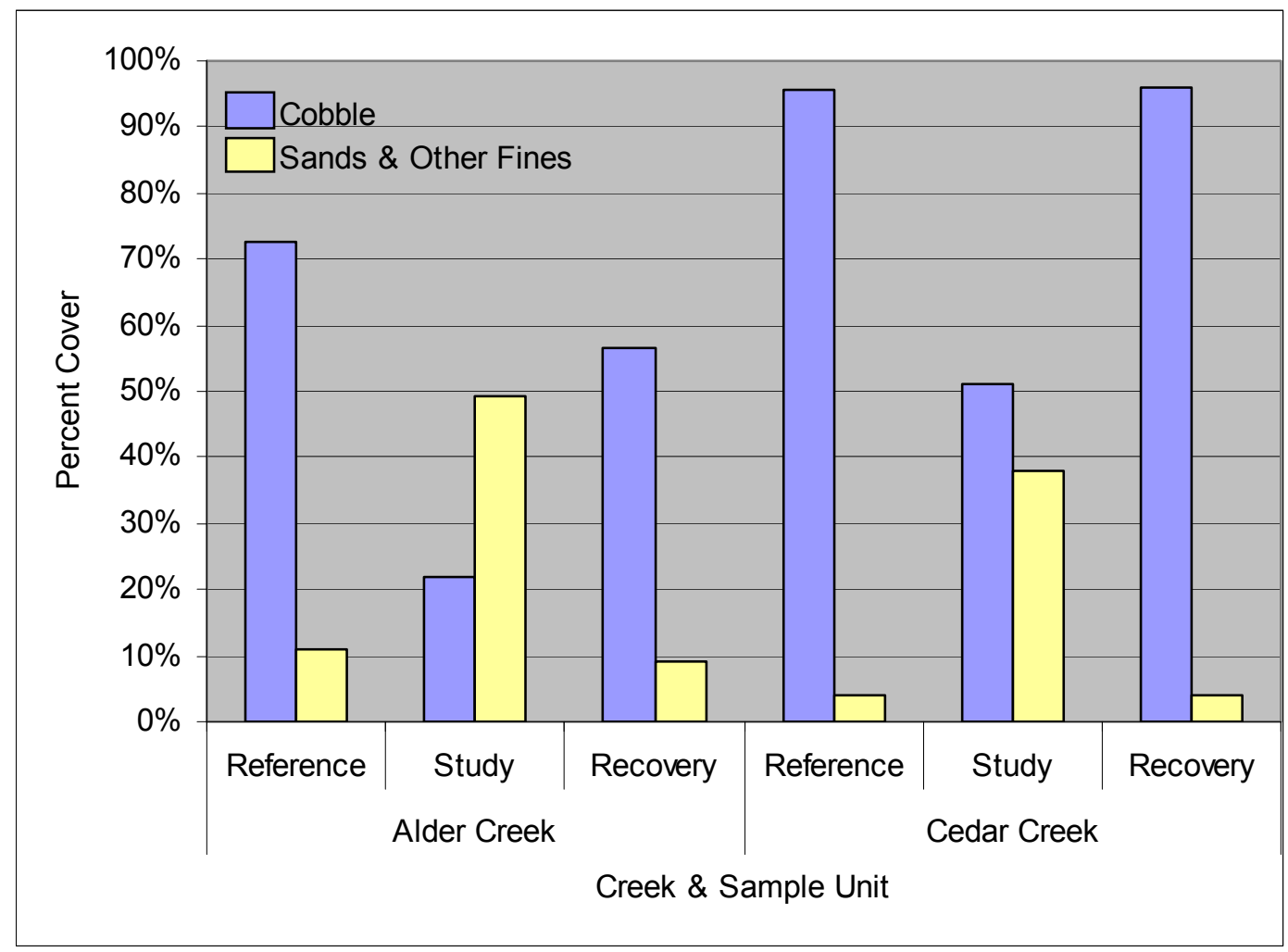

Figure 3. Alteration of cobble and sands and other fines instream microhabitats for Alder and Cedar Creek sample units.

The first, second, and third quartiles (D25, D50, D75) of the Wolman pebble count (Table 3) showed an interesting trend, with a decrease in average size at the study sample units compared to the reference and recovery sample units.

\begin{tabular}{|c|c|c|c|c|}
\hline \multicolumn{5}{|c|}{ Average Substrate Size } \\
\hline \multicolumn{2}{|c|}{ Sample Unit } & $\mathrm{D} 25$ & D50 & D75 \\
\hline \multirow{3}{*}{ Alder Creek } & Reference & 22.6 & 32.0 & 45.0 \\
\hline & Study & 5.6 & 11.0 & 22.6 \\
\hline & Recovery & 22.6 & 32.0 & 32.0 \\
\hline \multirow{3}{*}{ Cedar Creek } & Reference & 90.0 & 180.0 & 250.0 \\
\hline & Study & 2.0 & 12.0 & 99.5 \\
\hline & Recovery & 128.0 & 180.0 & 250.0 \\
\hline
\end{tabular}

Table 3. First, second, and third quartile of Wolman pebble count.

Measurements of diameter in millimeters.

The measurement of fine sediment cover (Table 4) showed the Alder and Cedar Creek study sample units had up to four times more fine sediment than the respective reference and recovery sample units. 


\begin{tabular}{|c|c|c|}
\hline \multicolumn{3}{|c|}{ Fine Sediment Cover } \\
\hline \multicolumn{2}{|c|}{ Sample Unit } & Measurement \\
\hline \multirow{3}{*}{ Alder Creek } & Reference & $6 \%$ \\
\hline & Study & $68 \%$ \\
\hline & Recovery & $22 \%$ \\
\hline \multirow{3}{*}{ Cedar Creek } & Reference & $2 \%$ \\
\hline & Study & $80 \%$ \\
\hline & Recovery & $0 \%$ \\
\hline
\end{tabular}

Hydrology between the sample units for both stream reaches was considerably altered.

At the study sample unit the average channel width and depth increased by about two times, while the average velocity decreased by up to more than half. The reference and recovery sample unit measurements were more similar to each other than to the study sample units.

\begin{tabular}{|c|c|c|c|c|}
\hline \multicolumn{4}{|c|}{ Physical Channel Measurements } \\
\hline \multirow{7}{*}{} & $\begin{array}{c}\text { Width } \\
\text { Avg (m) }\end{array}$ & $\begin{array}{c}\text { Depth } \\
\text { Avg (m) }\end{array}$ & $\begin{array}{c}\text { Velocity } \\
\text { Avg (m/s) }\end{array}$ \\
\hline \multirow{3}{*}{ Sample Unit } & Reference & 2.60 & 0.19 & 0.43 \\
\cline { 2 - 5 } Alder Creek & Study & 3.64 & 0.49 & 0.33 \\
\cline { 2 - 5 } & Recovery & 1.99 & 0.30 & 0.55 \\
\hline \multirow{3}{*}{ Cedar Creek } & Reference & 2.30 & 0.15 & 0.38 \\
\cline { 2 - 5 } & Study & 5.22 & 0.29 & 0.03 \\
\cline { 2 - 5 } & Recovery & 3.08 & 0.16 & 0.48 \\
\hline
\end{tabular}

Table 4. Average width, depth, and velocity in meters.

Cedar Creek was heavily shaded with 95\% canopy cover in both reference and recovery sample units while Alder Creek was relatively open. The average canopy cover (Table 5) at the reference and recovery sample units were both greater than the canopy cover at the study sample units. The reduction of canopy cover was more pronounced in Alder Creek (73\% reduction) than in Cedar Creek (17\% reduction). 


\begin{tabular}{|l|c|c|}
\hline \multicolumn{3}{|c|}{ Canopy Cover } \\
\hline \multicolumn{2}{|c|}{ Sample Unit } & Average \\
\hline \multirow{3}{*}{ Alder Creek } & Reference & $30 \%$ \\
\cline { 2 - 3 } & Study & $8 \%$ \\
\cline { 2 - 3 } & Recovery & $10 \%$ \\
\hline \multirow{3}{*}{ Cedar Creek } & Reference & $95 \%$ \\
\cline { 2 - 3 } & Study & $79 \%$ \\
\cline { 2 - 3 } & Recovery & $95 \%$ \\
\hline
\end{tabular}

Water quality measurements (Table 6) showed a distinction between the Alder and Cedar Creek stream reaches. The measurements, Specific Conductance ( $\mathrm{SpC} \mu \mathrm{S} / \mathrm{cm})$, Temperature (Temp ${ }^{\circ} \mathrm{C}$ ), and Total Dissolved Solids (TDS g/L) were greatest in the Cedar Creek stream reach. The measurements, Dissolved Oxygen (DO mg/L) and pH were greatest in the Alder Creek stream reach. Within each stream reach there was little variation of water quality, with the exception of the $\mathrm{pH}$ measurement.

\begin{tabular}{|c|c|c|c|c|c|c|c|}
\hline \multicolumn{7}{|c|}{ Water Quality } \\
\hline \multicolumn{2}{|c|}{ Sample Unit } & SpC $\mu$ S/cm & Temp ${ }^{\circ} \mathrm{C}$ & DO\% & DO mg/L & TDS g/L & $\mathrm{pH}$ \\
\hline \multirow{3}{*}{ Alder Creek } & Reference & 50.582 & 7.37 & 109.2 & 10.61 & 32.91 & 9.81 \\
\cline { 2 - 8 } & Study & 50.188 & 7.34 & 110.1 & 10.72 & 32.61 & 9.17 \\
\cline { 2 - 8 } & Recovery & 50.001 & 7.31 & 109.8 & 10.47 & 32.54 & 7.51 \\
\hline \multirow{3}{*}{ Cedar Creek } & Reference & 67.528 & 12.86 & 110.1 & 8.67 & 43.90 & 6.49 \\
\cline { 2 - 8 } & Study & 67.591 & 12.14 & 109.3 & 8.74 & 44.00 & 7.80 \\
\cline { 2 - 8 } & Recovery & 67.832 & 11.64 & 107.2 & 8.70 & 44.12 & 7.51 \\
\hline
\end{tabular}

Table 6. Water quality measurements.

The non-metric multi-dimensional scaling (NMDS stress: 2.399344e-14) plot, with a Bray-Curtis (BC) distance (Figure 4) overlay, shows the distance, or dissimilarity, between sample units. The greatest dissimilarity was found between the reference and study sample units. For the Alder Creek stream reach, the BC distance at the reference sample unit (AU) and the study sample unit (AC) was 0.43. For the Cedar Creek stream reach, the BC distance at the reference sample unit (CU) and the recovery sample unit (CC) was 0.46. 


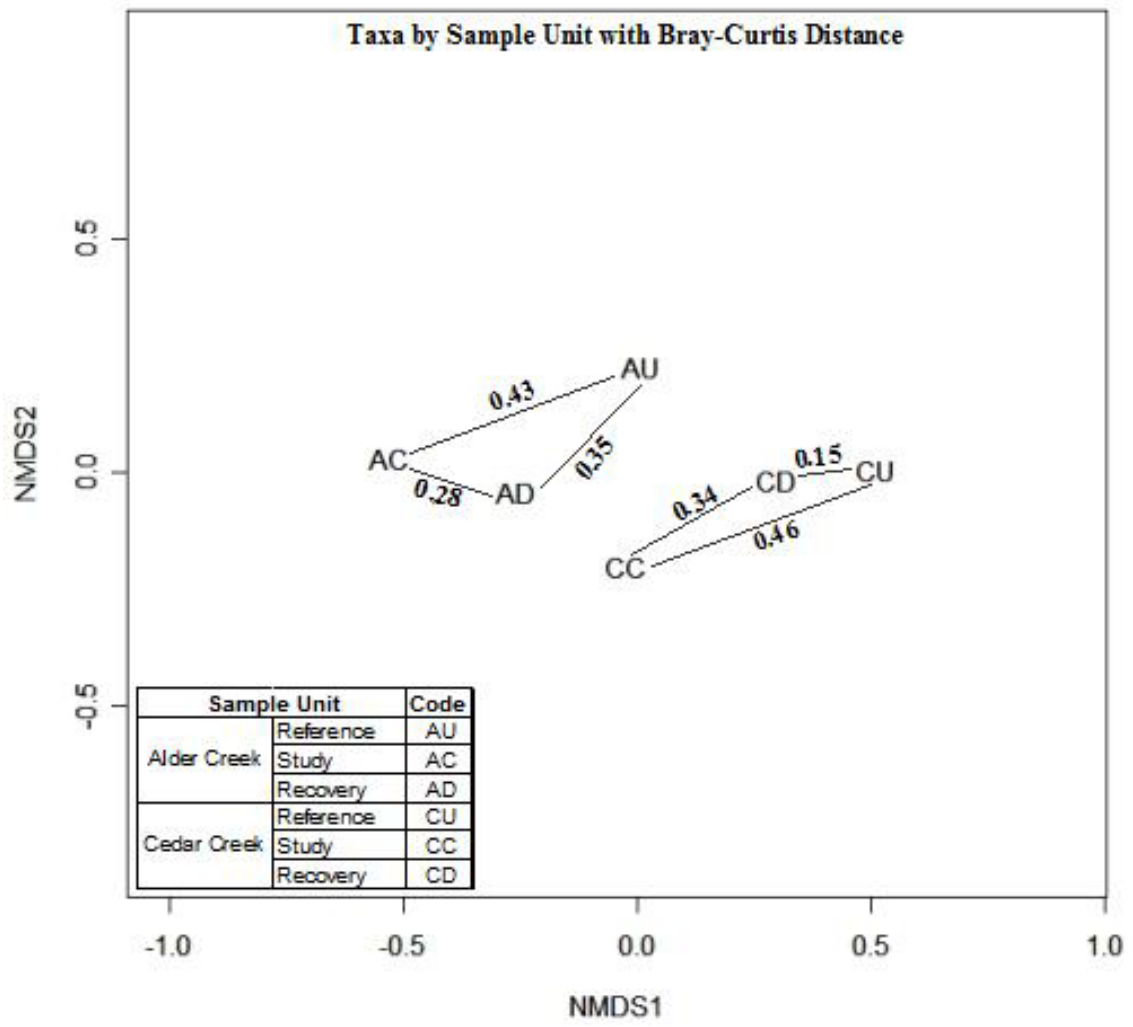

Figure 4. NMDS plot of sample units and Bray-Curtis distance.

The proportion of Ephemeroptera, Plecoptera, and Trichoptera (EPT) taxa (Figure 5) followed a similar trend at both stream reaches. The EPT taxa in the Alder Creek stream reach was $80 \%$ at the reference sample unit (AU). It decreased to $63 \%$ at the study sample unit (AC) and increased to $72 \%(\mathrm{AD})$ at recovery sample unit. In the Cedar Creek stream reach, the EPT taxa was $68 \%$ at the reference sample unit (CU). EPT decreased to $62 \%$ at the study sample unit (CU) and increased to 69\% at the recovery sample unit (CD). In both stream reaches, EPT taxa were more prevalent at the reference and recovery sample units. 


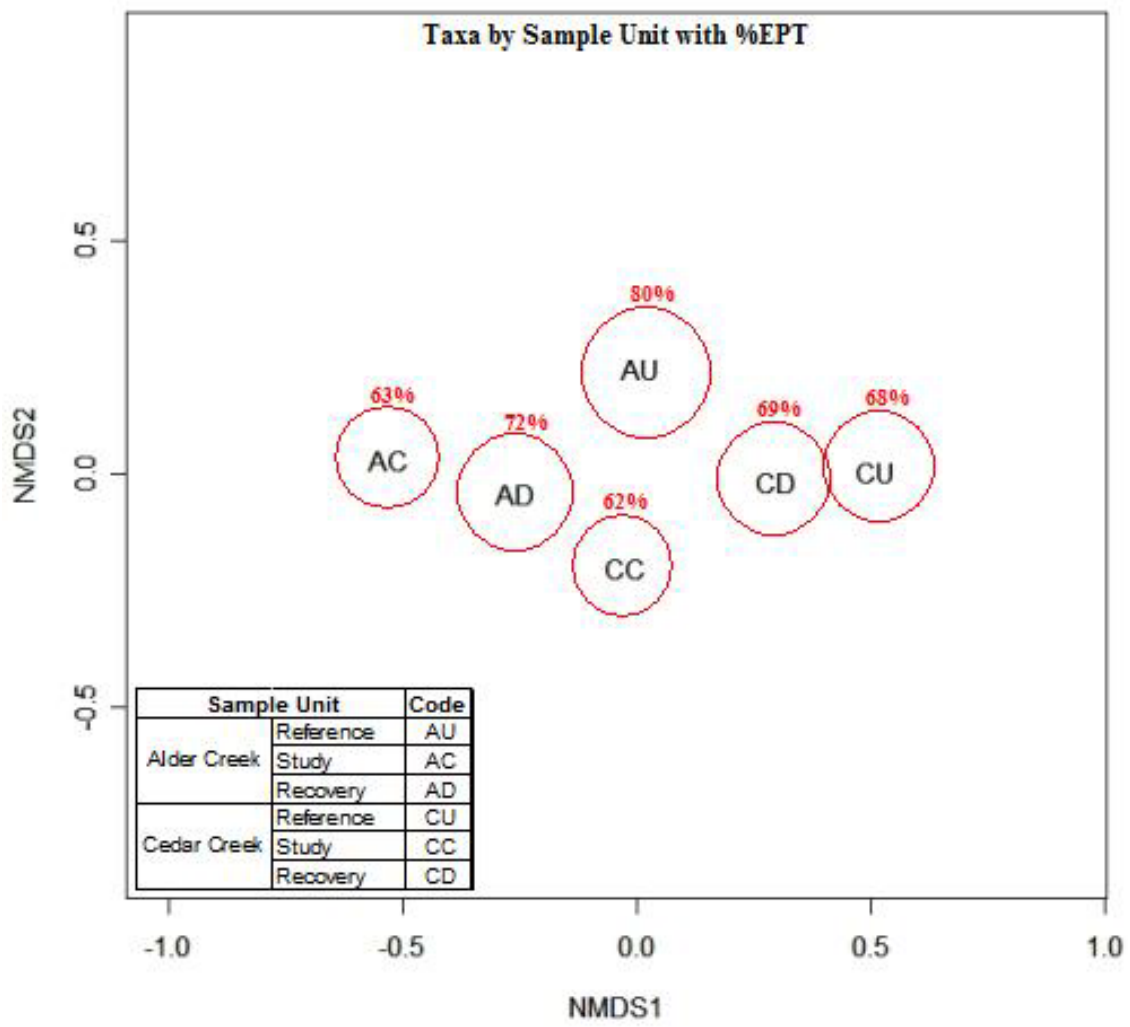

Figure 5. NMDS plot of sample units and percent of EPT taxa.

The dominant feeding groups (Figure 6) in the Alder and Cedar Creek stream reaches were scrapers and collector-gatherers. The scraper functional feeding group dominated the reference (AU, CU) and recovery (AD, CD) sample units. The dominant feeding group at the study sample units (AC, CC) was the collector-gatherer feeding group. 


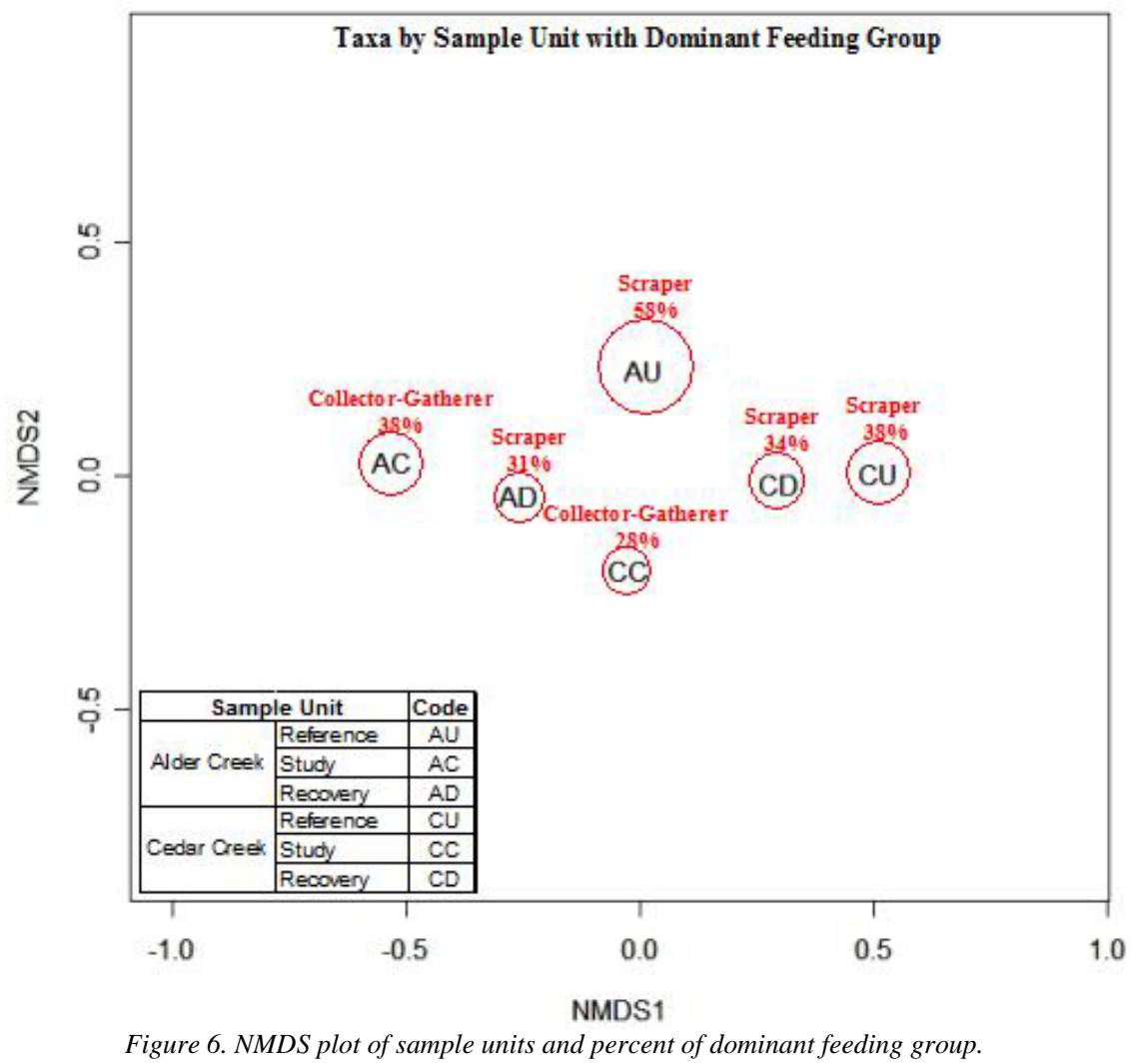

Environmental fitting (Figure 7) of physical and water quality measurements against the benthic macroinvertebrate community data showed the variables most likely to exert control on the structure of the benthic macroinvertebrate community. The instream microhabitat of cobble and the average substrate size D75 (third quartile) were significantly correlated $(\mathrm{P}<0.05)$ to the structure of the benthic macroinvertebrate community. Percent cobble was higher in Cedar Creek than in Alder Creek. However, within each creek, percent cobble decreased from the reference unit to study unit. On the other hand, the average substrate size D75 mainly reflected the substrate differences between two streams. 


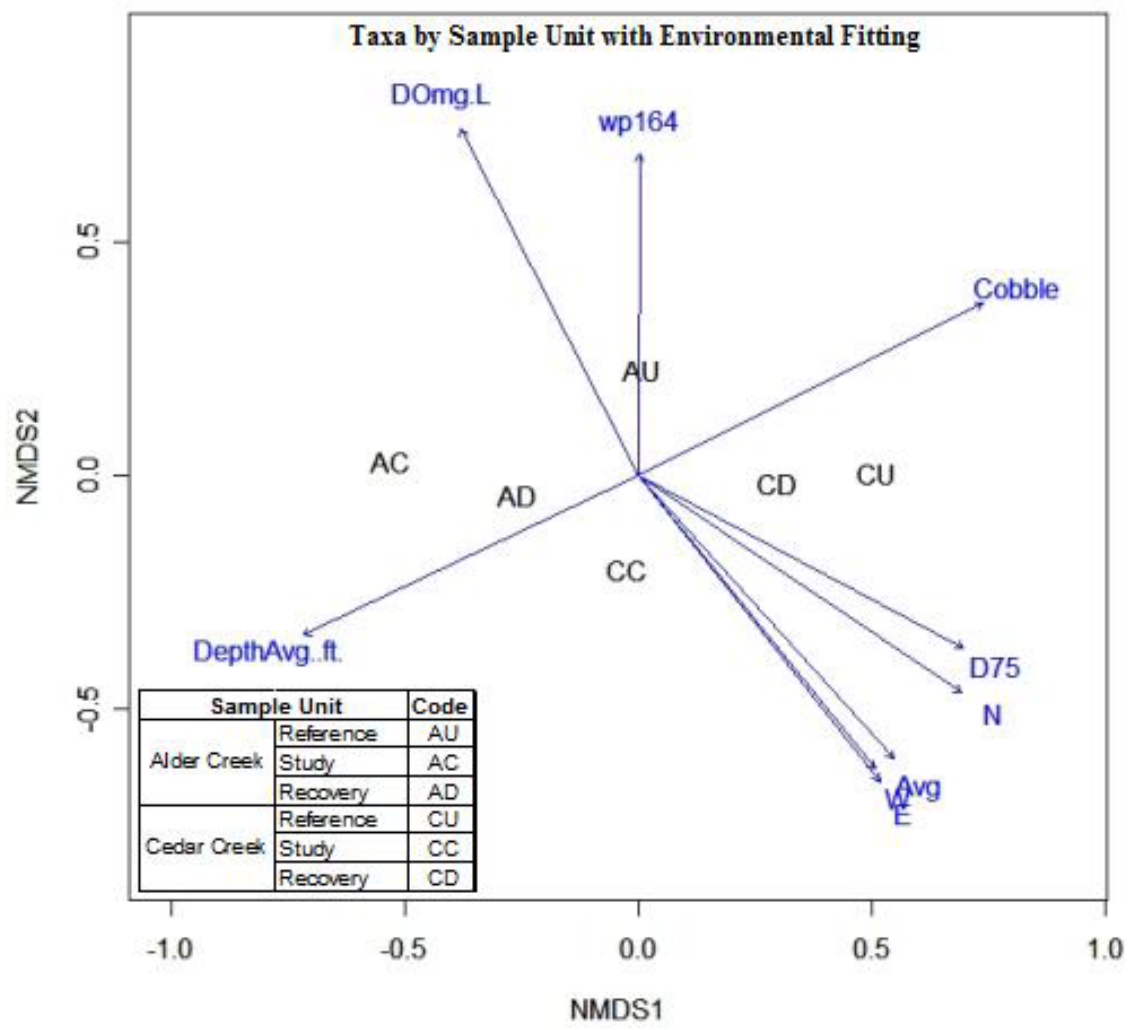

Figure 7. NMDS plot of sample units and environmental fitting.

\section{Discussion}

Environmental stress induced by road culverts may substantially alter stream ecology.

NMDS (Figure 4) is used to show the strongest pattern within a set of ecological data (McCune and Grace 2002). In the NMDS plot there is a clear separation of the Alder and Cedar Creek stream reaches based on the benthic macroinvertebrate data. This is expected, as no lotic ecosystem is exactly similar. More interesting are the patterns between the sample units within each stream reach. The reference sample units are further from the study sample units than they are from the recovery sample units. This could indicate that the culvert is responsible for altering the benthic macroinvertebrate community. This is especially evident at the Cedar Creek stream reach since reference and recovery sample units are close to each other. Based on family level taxonomy, the BC distance (Figure 4) shows trends that lend support to the alteration of the benthic macroinvertebrate community in relation to the culvert. The distance, or dissimilarity, 
(Oksanen updated 2009 Feb 2) between the reference and recovery sample units is less than the reference sample unit distance to the study sample units. This shows the benthic macroinvertebrate community at the study sample units is most dissimilar to the reference sample units. The recovery and reference sample units on the Cedar Creek stream reach are the least distant from each other, indicating these sample units have similar benthic macroinvertebrate communities. In this longitudinal study design, the BC distance between the reference and study sample units indicate the presence of a disturbance that alters the benthic macroinvertebrate community. The shortest BC distances are found between the Alder and Cedar Creek reference and recovery sample units. This may indicate that the benthic macroinvertebrate communities have recovered from a disturbance located somewhere between the two sample units.

Adverse effects of road culverts on stream ecology are evident as indicated by declining of EPT taxa in the sites below road culverts. The EPT taxa (Figure 5) are generally recognized as the most sensitive taxa to chemical and physical stressors of lotic ecosystems. Because of this sensitivity to stressors, they can be used to determine if there is an alteration to ecological conditions (Barbour et. al. 1999; Lenat and Penrose 1996; Merit and Cummins 1996; Voshell 2002). There was a consistent pattern of EPT taxa between Alder and Cedar creek sample units. The highest proportion of EPT taxa were collected at the reference sample units followed by the recovery sample units. The lowest proportion of EPT taxa was collected at the study sample units. Barbour et. al. (1999) indicate the proportion of EPT taxa will decrease in response to stressors. The lower proportion of EPT taxa at the study sample units points to the presence of a stressor that is altering the local ecology. The proportion of EPT taxa may be influenced by morphohydraulic units (MUs). In a study by Pastuchova et. al. (2008), the abundance of EPT 
taxa corresponded to morphohydraulic units. They found EPT taxa are most abundant in rapidtype (fast-flowing water) MUs. This corroborates the findings in this study where EPT taxa were most common at the reference and recovery sample units where water velocity was greatest.

Presence of road culverts may also alter the dominant benthic macroinvertebrate functional feeding groups (FFGs) (Figure 6). Grouping of feeding groups within the benthic macroinvertebrate community is a way to link the benthic fauna, through their morphology and adaptations to food source acquisition, to the physical environment. The similarity of the FFG is expected to alter with the availability of habitat (Merritt and Cummins 1996). In the reference sample units the benthic macroinvertebrate community was composed of a greater proportion of the scraper FFG. These sample units, when compared to the study sample units, were composed primarily of cobble instream microhabitat. They had a larger average substrate size and greater water velocities. The scraper FFG group is morphologically adapted so they are able to feed upon algae, which commonly grows on larger substrate sizes in faster flowing water (Voshell 2002). The greatest FFG proportion in the study sample units was the collector-gatherer. This functional grouping is synonymous with environmental conditions where detritus has fallen out of suspension and is either positioned on or mixed within the substrata. The benthic fauna in this group have evolved to move and feed on top of or within the substrata (Voshell 2002) where food sources have collected. The dominant functional feeding groups seem to be correlated with the sample units that are best suited to fulfill their needs based on their morphological adaptations to the physical environment. This type of pattern is not uncommon. Wallace and Webster (1996) found the physical environment is correlated to the presence and abundance of functional feeding groups. 
Alteration in physical habitats induced by road culverts may closely associate with the changes in macroinvertebrate assemblages. There was considerable alteration of instream microhabitat within each stream reach. Environmental interpretation (Oksanen updated 2009, Feb 12) of the physical and water quality data (Figure 7) showed that cobble instream microhabitat and substrate characterization classification of D75 were significant $(\mathrm{P}<0.05)$ to the composition of the benthic macroinvertebrtate community.

Substrate is an important component of the habitat for benthic fauna. Duan et. al. (2008) found that substrate size has a considerable affect on the macroinvertebrate assemblage. Large substrates like hewn stones, cobbles, and pebbles provide greater interstitial space that macroinvertebrates use as primary habitat and a refuge from physical disturbance and predation. Buss et. al. (2004) found similar results. Their study showed that the benthic macroinvertebrate community was affected by the availability of substrate size and that the availability of substrate is affected by hydrology. This is similar to the findings of this study. The benthic macroinvertebrate community was affected by the availability of substrate size, and the substrate size seemed to be affected by the water velocity, as there was a clear sorting centered on the road culvert, where velocities within the stream reach differed.

\section{Conclusion and limitations of the study}

This study showed correlations between the composition of the benthic macroinvertebrate community and the presence of road culverts. While these are interesting correlations, the study's spatial and biologic scales limit them. Future investigations should include more stream reaches, with more sample units. This would allow a greater variability in stream reach conditions and longitudinal environmental range to be investigated. There are stressor-related generalities at the family taxonomic level. Taxonomic resolution should be increased to genus. 
Physiology and morphology are less generalized at this level and the community composition should be more strongly altered by stressors. These measures would increase the ability to test, more precisely, whether a road culvert affects the benthic macroinvertebrate community, how it is affected, what the stressors are, and how the local ecology is affected. 


\section{$\underline{\text { References }}$}

Abt SR, Thompson PL. 1996. Scour at Culvert Outlets: Present and Future Considerations. In: Richardson EV, Lagasse PF, editors. Compendium of Papers ASCE Water Resources Engineering Conferences 1991 to 1998. American Society of Civil Engineers. pp. 825826.

Anon. 2004. R: A language and environment for statistical computing. R Foundation for Statistical Computing. Vienna (AT).

Barbour MT, Gerritsen J, Snyder BD, and Stribling JB. 1999. Rapid Bioassessment Protocols for Use in Streams and Wadeable Rivers: Periphyton, Benthic Macroinvertebrates and Fish, Second Edition. (DC): U.S. Environmental Protection Agency; Office of Water. EPA 841-B-99-002.

Buss BF, Baptista DF, Nessimian JL, Egler M. 2004. Substrate specificity, environmental degradation and disturbance structuring macroinvertebrate assemblages in neotropical streams. Hydrobiologia. 518: 179-188.

Carter JL, Resh VH, Hannaford MJ, Myers MJ. 2006. Methods in Stream Ecology. Burlington(MA): Academic Press. pp. 805 -808.

Clarke KR. 1993. Non-parametric multivariate analyses of changes in community structure. Austral Ecology. 18(1):117-143.

David Evans and Associates, Inc. 2000. Scappoose Bay Watershed Assessment. Prepared for the Scappoose Bay Watershed Council. Scappoose, OR. Available from: http://www.scappoosebay-wc.org/contents/assessment.pdf

Duan X, Wang Z, Tian S. 2008. Effect of streambed substrate on macroinvertebrate biodiversity. Frontiers of Environmental Science \& Engineering in China 47(9): 1553-1556.

Foreman RTT, Sperling D, Bissonette JA, Clevenger AP, Cutshall CD, Dale VH, Fahrig L, France R, Goldman CR, Heanue K, Jones JA, Swanson FJ, Turrentine T, Winter TC. 2003. Road Ecology: Science and Solutions. Washington (DC): Island Press. pp. 244247.

Hauer RF, Resh VH. 2006. Methods in Stream Ecology. Burlington(MA): Academic Press. pp. 435-443.

Jackson SD. 2003. Ecological Considerations in the Design of River and Stream Crossings. In: Proceedings of the International Conference of Ecology and Transportation. Irwin CL, Garrett P, McDermott KP Eds. 2003; NC: Center for Transportation and the Environment. (NC): Raleigh. pp. 20-29. 
Khan B, Colbo MH. 2008. The impact of physical disturbance on stream communities: lessons from road culverts. Hydrobiologia 600: 229-235

Lenat DR, Penrose DL. 1996. History of the EPT richness metric. Bulletin of the North American Benthological Society 13(2).

McCafferty WP, Provonsha AV. 1998. Aquatic Entomology: The Fishermen's and Ecologists' Illustrated Guide to Insects and Their Relatives. Sudbury (MA): Jones and Bartlett Publishers.

McCune B, Grace JB. 2002. Analysis of Ecological Communiteis. Gleneden Beach (OR): MjM Software Design. pp. 125

Merritt RW, Cummins KW. 1996. An Introduction to the Aquatic Insects of North America. $3^{\text {rd }}$ ed. Dubuque (IA): Kendall/Hunt Publishing Company.

Pastuchova Z, Lehotsky M, Greskova A. 2008. Influence of morphohydraulic habitat structure on the invertebrate communities (Ephemeroptera, Plecoptera and Trichoptera). Biologia 63(5):720-729.

Oksanen J. [Internet]. [updated 2009 Feb 2]. Oulu (Finland): University of Oulu, Department of Biology; [cited 2009 Jul 23]. Available from: http://cc.oulu.fi/ jarioksa/opetus/metodi/vegantutor.pdf

Oksanen J. [Internet]. [updated 2009 Jun 12]. Oulu (Finland): University of Oulu, Department of Biology; [cited 2009 Jul 23]. Available from: http://cc.oulu.fi/ jarioksa/opetus/metodi/sessio3res.pdf

Resh VH. 2004. Stream crossings and the conservation of diadromous invertebrates in South Pacific island streams. Aquatic Conservation: Marine and Freshwater Ecosystems 15(3):313-317.

United States General Accounting Office. 2001. Restoring Fish Passage Through Culverts on Forest Service and BLM Lands in Oregon and Washington Could Take Decades. GAO02136. Washington D.C.

Vaughan MD. 2002. Potential Impact of Road-Stream Crossings (Culverts) on the Upstream Passage of Aquatic Macroinvertebrates. San Dimas (CA): The United States Forest Service. San Dimas Technology and Development Center.

Voshell JR. 2002. A Guide to Common Freshwater Invertebrates of North America. Blacksburg (VA): The McDonald \& Woodward Publishing Company.

Wallace BJ, Webster JR. 1996. The Role of Macroinvertebrates in Stream Ecosystem Function. Annual Review of Entomology 41:115-139. 
Ward JV. 1989. The Four-Dimensional Nature of Lotic Ecosystems. The North American Benthological Society 8(1):2-8

Warren ML, Pardew MG. 1998. Road Crossings as Barriers to Small-Stream Fish Movement. Transactions of the American Fisheries Society 127(4)637-644.

Wolman MG. 1954. A Method for Sampling Coarse River-Bed Material. Transactions of the American Geophysical Union 35(6):951-956. 